\title{
Effects of Ectopic Expression of NGAL on Doxorubicin Sensitivity.
}

\author{
William H. Chappell ${ }^{1}$, Stephen L. Abrams ${ }^{1}$, Giuseppe Montalto ${ }^{2,3}$, Melchiorre \\ Cervello ${ }^{3}$, Alberto M. Martelli, ${ }^{4,5}$, Saverio Candido ${ }^{6}$, Massimo Libra ${ }^{6}$, Jerry Polesel7, \\ Renato Talamini ${ }^{7}$, Ralph Arlinghaus ${ }^{8}$, Linda S. Steelman ${ }^{1}$ and James A. McCubrey ${ }^{1}$ \\ ${ }^{1}$ Department of Microbiology \& Immunology, Brody School of Medicine, East Carolina University, Greenville, NC, USA 27834 \\ 2 Department of Internal Medicine and Specialties, University of Palermo, Palermo, Italy \\ ${ }^{3}$ Consiglio Nazionale delle Ricerche, Istituto di Biomedicina e Immunologia Molecolare "Alberto Monroy", Palermo, Italy \\ ${ }^{4}$ Department of Biomedical and Neuromotor Sciences, Università di Bologna, Bologna, Italy \\ ${ }^{5}$ Institute of Molecular Genetics, National Research Council-Rizzoli Orthopedic Institute, Bologna, Italy \\ ${ }^{6}$ Department of Bio-Medical Sciences, University of Catania, Catania, Italy \\ ${ }^{7}$ Unit of Epidemiology and Biostatistics, Centro di Riferimento Oncologico, IRCCS, Aviano, Italy. \\ ${ }^{8}$ Department of Molecular Pathology, MD Anderson Cancer Center, University of Texas, Houston, TX \\ Correspondence to: James A. McCubrey, email: mccubreyj@ecu.edu
}

Keywords: NGAL, LCn2, Doxorubicin, lipocalins, siderocalins, iron transport, MMP-9, drug resistance

Received: October 01, 2012, Accepted: October 18, 2012, Published: October 20, 2012

Copyright: @ Chappell et al. This is an open-access article distributed under the terms of the Creative Commons Attribution License, which permits unrestricted use, distribution, and reproduction in any medium, provided the original author and source are credited.

\section{ABSTRACT:}

Neutrophil gelatinase-associated lipocalin (NGAL, a.k.a Lnc2) is a member of the lipocalin family which has diverse roles including stabilizing matrix metalloproteinase-9 from auto-degradation and as siderocalins which are important in the transport of iron. NGAL also has important biological functions involved in immunity and inflammation as well as responses to kidney damage. NGAL expression has also been associated with certain neoplasia and is important in the metastasis of breast cancer. Many advanced cancer patients have elevated levels of NGAL in their urine and it has been proposed that NGAL may be a prognostic indicator for certain cancers (e.g. breast, brain, and others). NGAL expression is detected in response to various chemotherapeutic drugs including doxorubicin and docetaxel. We were interested in the roles of NGAL expression in cancer and whether it is associated with chemotherapeutic drug resistance. In the present study, we investigated whether increased NGAL expression led to resistance to the chemotherapeutic drug doxorubicin in normal breast epithelial cells (MCF-10A), breast cancer cells (MCF7), and colorectal cancer cells (HT-29). We infected the various cell lines with a retrovirus encoding NGAL which we constructed. Increased NGAL expression was readily detected in the NGAL-infected cells but not the empty vector-infected cells. However, increased NGAL expression did not alter the sensitivity of the cells to the chemotherapeutic drug doxorubicin. Thus, although NGAL expression is often detected after chemotherapeutic drug treatment, it by itself, does not lead to doxorubicin resistance.

\section{INTRODUCTION}

Identifying the pathways activated and critical for cancer initiation and subsequent spread (invasion and metastasis) are essential for improved cancer therapy. Also, it is essential to understand how cells develop resistance to various therapeutic approaches and whether the resistance results from intrinsic or extrinsic events. Over the past 35 years, many genes have been identified which can cause or contribute to cancer [1,2]. These include two major classes of genes, the oncogenes and the tumor suppressor genes [3,4]. Moreover, microRNAs (miRNAs) and epigenetic modifications have been shown to be important in regulating cancer progression [5-8]. In some cases, 
the genetic culprit involved in a particular cancer may be known (e.g., BCR-ABL in chronic myeloid leukemia $[9,10]$. However, in most cases, there are multiple genetic and epigenetic events occuring which interact and develop into a cancer cell capable of becoming metastatic and/ or drug resistant. In addition, there are other important contributions by the tumor microenvironment which aid in the progression of the cancer as well as resistance to various therapeutic approaches and the survival of cancer initiating cells [11-13].

One factor which may be important for cancer survival and metastasis is neutrophil gelatinase-associated lipocalin (NGAL). One of the genomic responses to common cancer treatments such as radiation and chemotherapy is the induction of NGAL expression [1419]. NGAL may act to stabilize MMP-9 and increase its ability to degrade the extracellular matrix, hence promoting metastasis.

NGAL expression is regulated by the transcription factors: NF-kappaB, CEBP and others [20-24]. Radiation and chemotherapy may induce reactive oxygen species (ROS) that result in NF-kappaB activation [25,26] and subsequent downstream NGAL transcription. In addition, the tumor microevironment may alter NF-kappaB activity [27]. Chemo- and radiotherapy could result in the synthesis of NGAL in cancer cells which may lead to the development of therapy-resistant cells. These cells can contribute to the reemergence and metastasis of the cancer as increased NGAL expression may allow the cells to persist under conditions where the therapy-sensitive cancer cells could not normally survive.

Cancer cells have increased demands for intracellular iron. NGAL is a member of the lipocalin family and as such is capable of serving as siderocalins or molecules involved in the transport of iron and other molecules [28]. Iron is essential for many key processes, including the rate-limiting step in DNA synthesis carried out by ribonucleotide reductase [29]. Iron $\left(\mathrm{Fe}^{++}\right)$is also

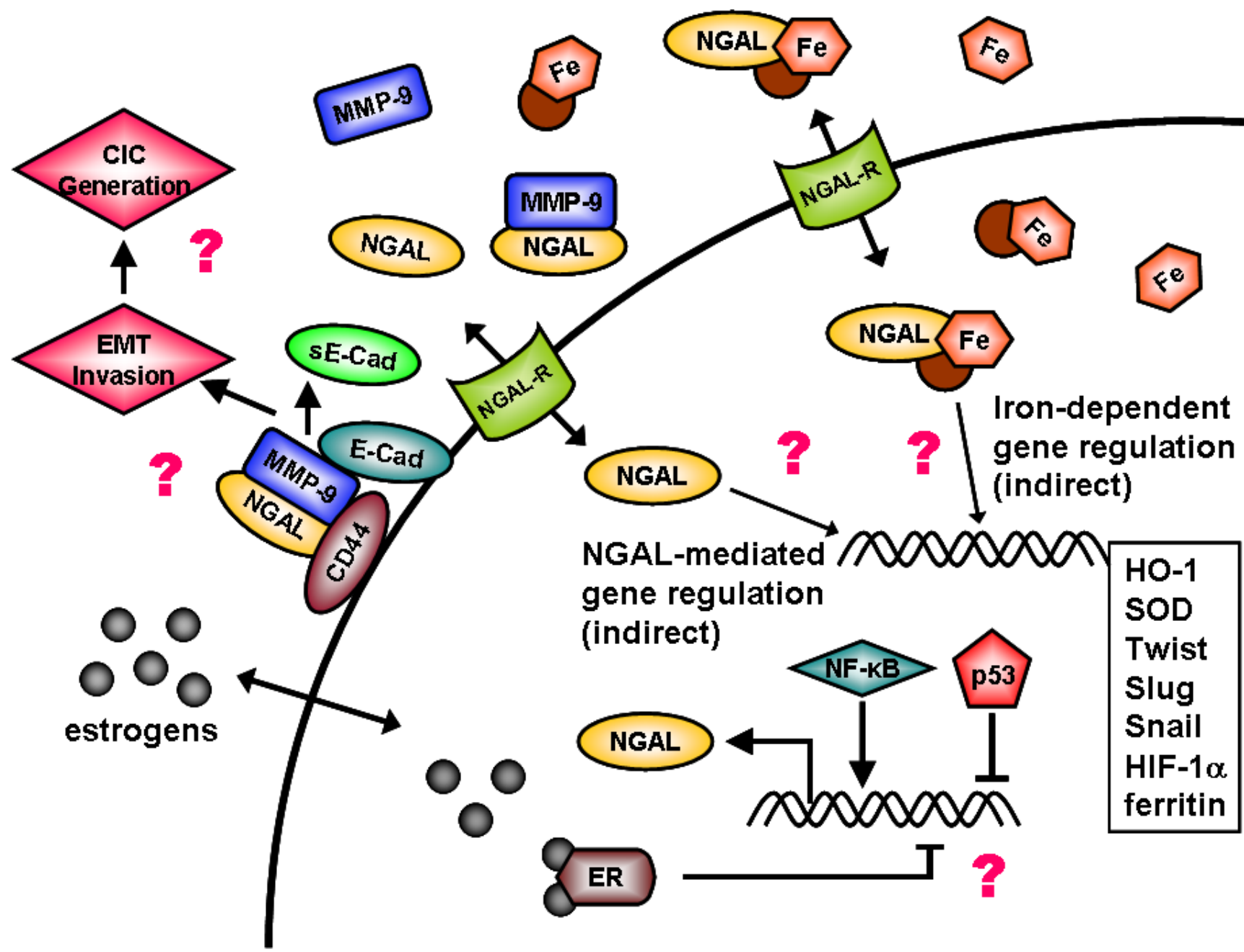

Figure 1: Overview of Potential Effects of NGAL on Cellular Growth. NGAL may serve diverse biochemical functions from stabilizing MMP-9 at the cellular membrane in association with CD44 and E-Cadherin (E-Cad), to roles in promoting EMT and invasion. In addition, NGAL may have roles in the transport of iron into the cell and influence iron-mediated gene expression. NGAL gene expression is infuenced by many transcription figures including NF- $\mathrm{KB}, \mathrm{p} 53$, and potential hormones such as the estrogen receptor (ER). Iron mediated gene expression is complex and can influence the expression of many genes involved in cancer metastasis such as Twist, Slug, and Snail. 
required for cells to progress through the cell cycle from $\mathrm{G}_{1}$ to $\mathrm{S}$ phase. Tumor cells have a high requirement for iron and express elevated levels of the transferrin receptor-1 [30-34]. Novel chelators of iron are being considered for cancer treatment [35]. Iron chelators, such as Desferrioxamine (DFO), inhibit cellular iron transport and have been evualated in various cancer clinical trials [36]. Oxygen and iron concentrations may be altered in the tumor microenvironment due to drastic tumor growth [37-40]. In order for a cancer cell to survive, invade, and metastasize it may have to have increased iron transport as well as elevated glycolysis [11-14,40,41]. The role of iron transport in chemotherapeutic drug resistance of cancer cells is complex and may depend on the particular drug and cancer type investigated $[42,43]$. Interestingly, some iron depletors have been shown to decrease resistance of certain cancer cells to chemotherapeutic drugs including doxorubicin $[44,45]$.

Increased levels of NGAL have been detected in the urine of patients with various types of cancer (i.e. brain, breast, colon, ovarian, pancreatic and prostate). Novel non-invasive urine-based tests could prove useful for the detection and/or prognosis of many cancer types [46-49].

The role(s) of NGAL in chemotherapeutic drug resistance, invasion, and cancer metastasis are not fully elucidated [15]. Targeting NGAL could result in decreased cancer cell survival and tumor regression

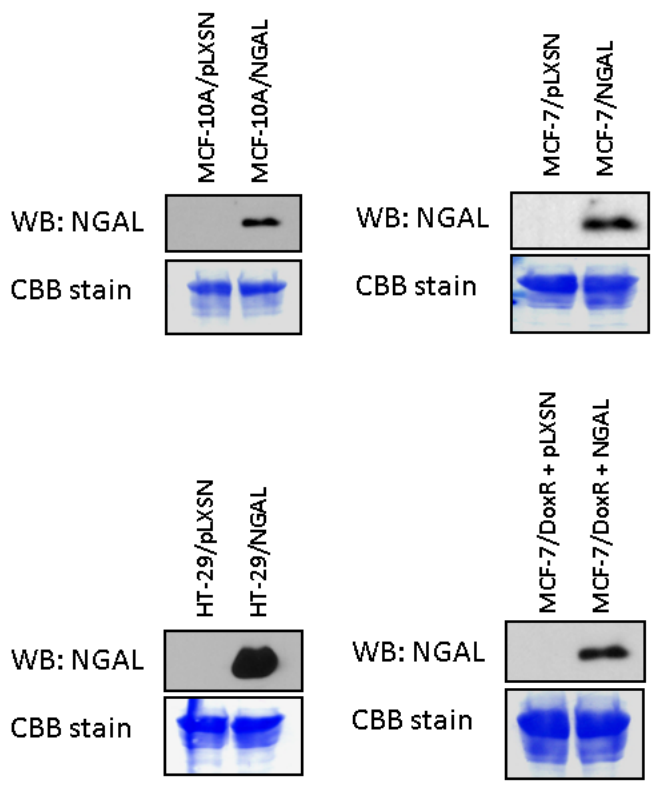

Figure 2: NGAL Expression in pLXSN and NGAL Infected Cells. pLXSN empty vector and NGAL infected MCF-10A, MCF-7, and HT-29T were cultured for 24 hours in the absence of FBS and then the supernatants were analyzed for the expression of NGAL as described in Material \& Methods. All the experiments in this figure were performed at the same time (set up on the same day). as well as improve the effectiveness of radiation and chemotherapy in cancer therapy. NGAL is considered by some scientists to have properties of an oncogene. It has been shown in some studies to increase the mobility, invasion, metastasis, and tumorigenesis of certain cancer cells [breast, colorectal cancer (CRC)] [50-52]. Elevated expression of NGAL increases the invasiveness of certain cancer cells, while inhibition of NGAL expression decreases their invasiveness and metastasis $[17,19,50]$. New approaches to target MMP-9/NGAL are needed as MMP-9 inhibitors have not performed well in clinical cancer trials [54] and NGAL has functions which are independent of MMP-9.

NGAL may exert many different effects that are important in invasion and metastasis. NGAL can stabilize MMP-9 at the cell surface [55-57]. This complex may be associated with CD44 which may promote the cleavage of E-Cadherin (E-Cad) into soluble (s)E-Cad thereby promoting EMT $[57,58]$. A diagram illustrating potential effects of NGAL on cell survival is presented in Figure 1. In the following studies, we examined the effects of ectopic NGAL expression on the sensitivity of breast cancer and $\mathrm{CRC}$ to a common chemotherapeutic drug used to treat many cancer patients (doxorubicin, a.k.a Adriamycin). We chose to examine the effects of ecotopic NGAL expression on sensitivity to doxorubicin on two different different types of cancers. Breast cancer which is generally sensitive to doxorubicin therapy and CRC which is considered resistant to doxorubicin therapy. An immortalized breast epithelial cell line, MCF-10A, was also examined in these studies.

\section{RESULTS}

\section{Infection of Cell Lines with a Retrovirus Encoding NGAL and Expression of Ectopic NGAL.}

MCF-10A, MCF-7, and HT-29 cells were infected with a retrovirus encoding NGAL or the empty retrovirus pLXSN. NGAL was detected in the supernatants from NGAL retrovirus infected cells (Figure 2). In contrast, NGAL was not detected in the empty vector pLXSN virus infected cells.

\section{Effects of Enforced NGAL Expression on Sensitivity to Doxorubicin.}

We next examined the effects of elevated NGAL expression on the sensitivity of the cell lines to doxorubicin using MTT assays. A representative MTT assay is presented in Figure 3. Also included in these anaylses were the effects of doxorubicin on a 

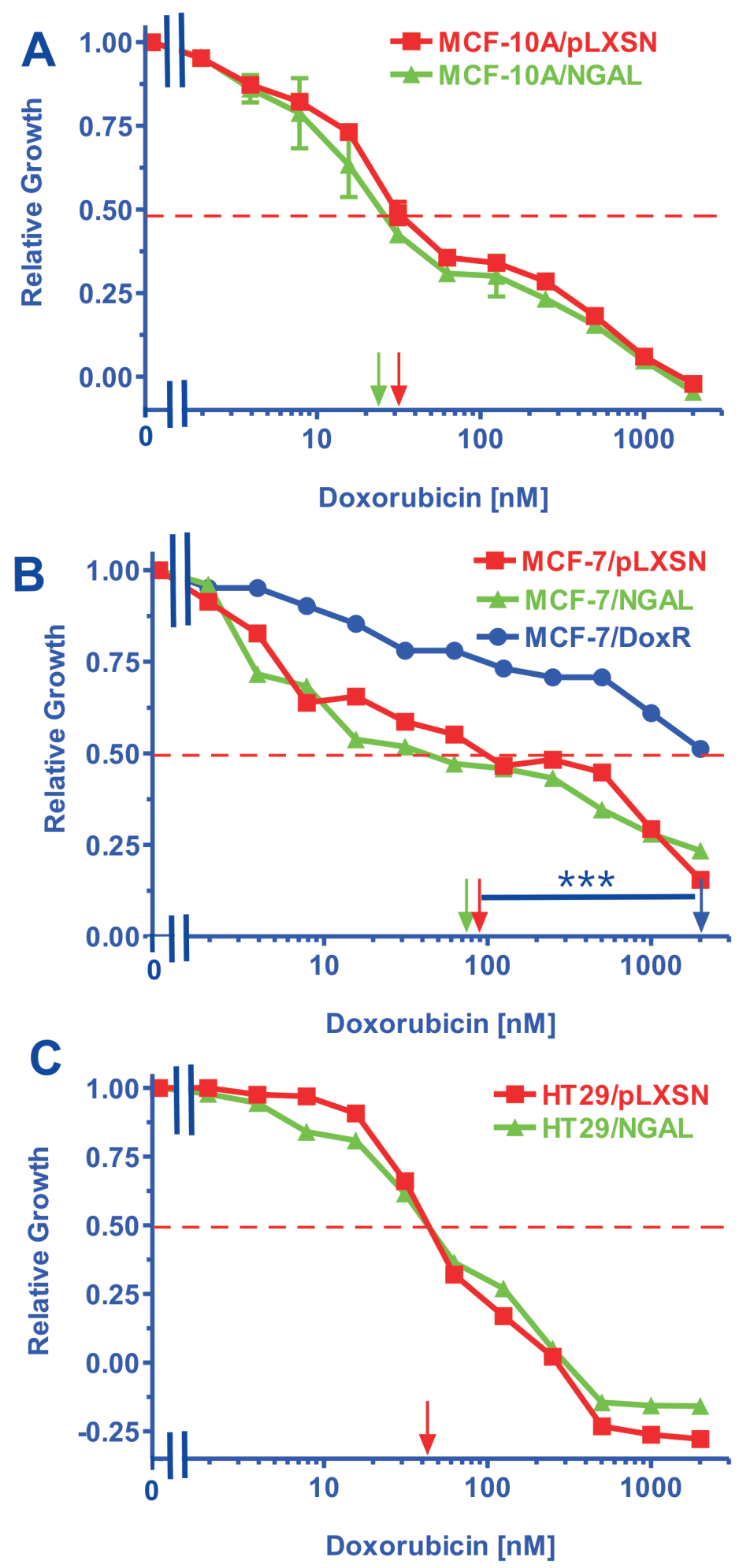

Figure 3: Doxorubicin $\mathrm{IC}_{50}$ analysis in NGAL and pLXSN Infected Cells and Doxorubicin-Resistant MCF-7/Dox ${ }^{\mathrm{R}}$ Cells. Cells were collected and seeded (2000 cells/well) in 96 well plates. The following day, serial two-fold dilutions of doxorubicin were added to the wells. Four days later, MTT assays were performed to determine the effects of doxorubicin on: Panel A) MCF-10A/pLXSN (solid squares), MCF-10A/NGAL (solid triangles), Panel B) MCF-7/pLXSN (solid squares), MCF-7/NGAL (solid triangles) and $25 \mathrm{nM}$ doxorubicin selected MCF-7/Dox ${ }^{\mathrm{R}}$ cells (solid circles), Panel C) HT-29/pLXSN (solid squares), HT-29/NGAL (solid triangles). A hatched horizontal line is present at the $50 \%$ relative growth mark from which the $\mathrm{IC}_{50}$ can be calculated. A veritical arrow indicates the $\mathrm{IC}_{50}$. The statistical significance was determined by the unpaired $t$ test $(* * *, \mathrm{P}<0.001)$. All the experiments in this figure were performed at the same time (set up on the same day). These experiments were repeated multiple times and similar results were obtained. 
Table 1: Effects of Ectopic NGAL Expression on the Doxorubicin IC50 in Cell Lines Derived from Different Cancer Types. ${ }^{1}$

\begin{tabular}{|l|l|l|}
\hline Cell Line & Type & Doxorubicin IC50 \\
\hline MCF-10A/pLXSN & $\begin{array}{l}\text { mammary luminal epithelial, } \\
\text { non malignant, near diploid }\end{array}$ & $32 \mathrm{nM}$ \\
\hline MCF-10A/NGAL & & $30 \mathrm{nM}$ \\
\hline MCF-7/pLXSN & breast cancer ER+, luminal & $90 \mathrm{nM}$ \\
\hline MCF-7/NGAL & & $80 \mathrm{nM}$ \\
\hline MCF-7/DoxR & doxorubicin resistant MCF-7 & $2000 \mathrm{nM}$ \\
\hline HT-27/pLXSN & colorectal cancer & $40 \mathrm{nM}$ \\
\hline HT-27/NGAL & & $40 \mathrm{nM}$ \\
\hline
\end{tabular}

${ }^{1}$ MTT analysis was performed with different unselected cancer lines and certain $25 \mathrm{nM}$ doxorubicin resistant (DoxR). Determined by plating 5,000 cells/well in 96 well plates in phenol red free RPMI $1640+10 \%$ FBS. Serial 2-fold dilutions ( $\mathrm{n}=12$ dilutions) of doxorubicin were dispensed into 8 wells per each doxorubicin concentration after the first day. MTT analysis was performed after 4 additional days of incubation and results were normalized to untreated cells as described [62].

doxorubicin-resistant MCF-7 line named MCF-7/Dox ${ }^{\mathrm{R}}$ (Chappell AER paper in press) that were performed at the same time. Clearly, the doxorubicin-resistant MCF-7/Dox ${ }^{\mathrm{R}}$ is approximately 20 -fold more resistant to doxorubicin than the MCF-7/pLXSN or MCF-7/NGAL cell lines demonstrating that NGAL expression alone does not confer doxorubicin resistance in these cells.

The doxorubicin $\mathrm{IC}_{50} \mathrm{~s}$ for various NGAL- and pLXSN-infected cell lines representing different tissues are presented in Table 1. Increased NGAL expression did not significantly ( $>2$-fold) alter the $\mathrm{IC}_{50} \mathrm{~s}$ for doxorubicin in the cell lines examined.

\section{DISCUSSION.}

These studies were undertaken to determine whether increased NGAL expression altered the sensitivity to the chemotherapeutic drug doxorubicin in cancer cell types which are normally sensitive to doxorubicin (breast) and cancer cell types which are normally resistant to doxorubicin (CRC) as well as immortalized breast epithelial cells (MCF-10A) which are not malignant. NGAL may have roles in iron transport which may be associated with chemoresistance in certain cancers. Some studies have shown that iron chelators will reduce chemotherapeutic drug resistance $[44,45]$. However, in our studies, elevated NGAL expression did not alter the sensitivity to doxorubicin of neither the breast cancer nor CRC cells examined. Additionally, it did not alter the sensitivity of the immortalized breast epithelial MCF-10A cells. Note, it is also conceivable that elevated NGAL expression could have made the cells more sensitive to doxorubicin, but that did not appear to occur in these cells, or other cells examined.

The doxorubicin resistant MCF-7/Dox ${ }^{\mathrm{R}}$ cell line was also infected with the retrovirus encoding NGAL (Figure 2), however, these cells were not more resistant to doxorubicin than empty vector control MCF-7/Dox ${ }^{\mathrm{R}}$ cells (data not presented). NGAL expression was not detected at higher levels in drug resistant MCF-7/Dox ${ }^{\mathrm{R}}+\mathrm{pLXSN}$ cells than MCF-7/pLXSN (Figure 2). Moreover, the doxorubicin resistant MCF-7/Dox ${ }^{R}$ cells do not normally express NGAL; however, upon treatment with doxorubicin increased NGAL protein has been detected [59]. Elevated NGAL expression does not appear, by itself, to increase the resistance to doxorubicin in the cells examined. Such changes could be occurring in the regulation of various signaling pathways or drug transporters in these cells.

Although NGAL expression has been associated with a poor prognosis in breast and other cancers $[24,60,61]$, elevated expression of NGAL does not alter the $\mathrm{IC}_{50}$ for the chemotherapeutic drug doxorubicin. Furthermore, elevated expression of NGAL did not alter the responses of either the CRC line HT-29 or the 
immortalized epithelial line MCF-10A to doxorubicin.

\section{MATERIALS \& METHODS.}

\section{Cell Lines and Growth Factors.}

The breast cancer (MCF-7) and CRC (HT-29) cell lines were obtained from the ATCC (Rockville, MD, USA). Cells were maintained in a humidified $5 \% \mathrm{CO}_{2}$ incubator at $37^{\circ} \mathrm{C}$ with RPMI-1640 [(RPMI) Invitrogen, Carlsbad, CA, USA] supplemented with 10\% fetal bovine serum (FBS) (Atlanta Biologicals, Atlanta, GA, USA). This complete RPMI media is abbreviated cRPMI. The immortalized breast epithelial MCF-10A line was obtained from the ATCC and cultured in DMEM/F12 (Invitrogen) medium containing: $2.5 \mathrm{mM}$ L-glutamine, supplemented with $5 \%$ heat inactivated equine serum (Invitrogen), $500 \mathrm{ng} / \mathrm{ml}$ hydrocortisone (Sigma-Aldrich), $21.5 \mathrm{ng} / \mathrm{ml}$ epidermal growth factor (EGF) (Sigma-Aldrich), $10 \mu \mathrm{g} / \mathrm{ml}$ insulin (Sigma-Aldrich), $100 \mathrm{ng} / \mathrm{ml}$ cholera toxin (SigmaAldrich), and 15mM HEPES (Sigma-Aldrich).

\section{Methylthiazol Tetrazolium Assay.}

Methylthiazol tetrazolium (MTT) assays were performed to determine a cell line's sensitivity to chemotherapeutic drugs. $2 \times 10^{3}$ cells per well were plated in 96-well plates in $100 \mu \mathrm{L}$ of cRPMI without phenol red (Invitrogen ${ }^{\mathrm{TM}}$, Carlsbad, CA) and allowed to attach overnight under normal culture conditions. The next day, serial two-fold dilutions of a chemotherapeutic drug were made and $100 \mu \mathrm{L}$ of each dilution were added to a corresponding well on the 96-well plate. Cells were incubated for four days under normal culture conditions. On the fourth day, $22.2 \mu \mathrm{L}$ of a $5 \mathrm{mg} / \mathrm{mL}$ solution of thiazolyl blue tetrazolium bromide (SigmaAldrich, Saint Louis, MO) in 1X PBS was added to each well and incubated for 90 minutes at $37^{\circ} \mathrm{C}$. The media was then removed and $150 \mu \mathrm{L}$ of dimethyl sulfoxide (DMSO) (Fisher Scientific, Pittsburgh, PA) was added to resuspend formazin crystals to produce a purple color which was subsequently read on a Multiskan EX Microplate photometer (Thermo Scientific, Hudson, $\mathrm{NH})$ at a wavelength of $570 \mathrm{~nm}$. Colormetric readings were normalized against plates of non-treated cells under identical culture conditions. Relative growth was calculated by dividing normalized cell growth values in the presence of drugs by normalized cell growth values in the absence of drugs and the results were graphed. Drug concentrations that killed at least $50 \%$ of the cells $\left(\mathrm{IC}_{50}\right)$ were determined from the calculated graphed values [62].

\section{Construction of Retroviral Vector Containing NGAL.}

The pLXSN/NGAL retroviral expression vector (referred to here and throughout this study as NGAL) was constructed using the retroviral vector $\mathrm{pLXSN}$ (Clontech ${ }^{\odot}$, Mountain View, CA) as the backbone. The full length cDNA of human NGAL (Lcn2, GenBank accession no. BC033089) was amplified from the pcDNA3.1(+)-NGAL plasmid [51] using specific primers for regions flanking either ends of the gene insert. The PCR product was then inserted into a pCR2.1-TOPOR TA vector (Invitrogen ${ }^{\mathrm{TM}}$, Carlsbad, CA), subsequently digested with EcoRI endonuclease (New England Biolabs ${ }^{\circledR}$, Ipswich, MA), and the resulting gene fragment was ligated into the EcoRI digested pLXSN vector.

\section{Packaging of Retroviral Vectors.}

Packaging of the retroviral vectors used in this study was as follows. $10 \mathrm{~mL}$ of a $0.1 \%$ gelatin/sterile water solution (Specialty Media, Chemicon/Millipore ${ }^{\mathrm{TM}}$, Billerica, MA) was used to gelatin coat Corning $75 \mathrm{~cm}^{2}$ flasks (Corning, NY) for one hour at room temperature and then removed. Following two subsequent washes with 1X phosphate buffered saline (PBS) $(110 \mathrm{mM}$ $\mathrm{NaCl}, 2.1 \mathrm{mM} \mathrm{KCl}, 1.1 \mathrm{mM} \mathrm{KH} \mathrm{PO}_{4}, 6.7 \mathrm{mM} \mathrm{Na}_{3} \mathrm{PO}_{4}$, $\mathrm{pH} 7.4), 6 \times 10^{6}$ total $293 \mathrm{~T}$ cells were plated in $10 \mathrm{~mL}$ cDMEM and allowed to adhere at $37^{\circ} \mathrm{C}$ overnight to the gelatin coated flasks. The next day, the culture media was removed and replaced with $10 \mathrm{~mL}$ fresh cDMEM one hour prior to transfection. DNA calcium phosphate precipitation was used to transfect 293T cells. $15 \mu \mathrm{g}$ of the packaging vector $\mathrm{pCL}$-Ampho (Imgenex ${ }^{\circ}$, San Diego, CA) was mixed with $35 \mu \mathrm{g}$ of $\mathrm{pLXSN} / \mathrm{NGAL}$, in $1.5 \mathrm{~mL}$ of $0.25 \mathrm{M} \mathrm{CaCl}_{2}$. This mixture was then added drop wise to $1.5 \mathrm{~mL}$ of $2 \mathrm{X}$ HBS (50 mM HEPES, $280 \mathrm{mM} \mathrm{NaCl}_{2}$, $1.5 \mathrm{mM} \mathrm{Na}_{2} \mathrm{HPO} 4, \mathrm{pH} 7.17$ ) and allowed to precipitate at room temperature for 45 minutes. After the precipitate incubation time, the solution of calcium-phosphate/DNA was added to the T75 flask of $293 \mathrm{~T}$ cells and incubated for six hours at $37^{\circ} \mathrm{C}$ in a humidified incubator with $5 \%$ $\mathrm{CO}_{2}$. Media was then removed and replaced with $9 \mathrm{~mL}$ of a $15 \%$ glycerol/PBS solution for one minute at room temperature. This solution was then removed and the cells gently washed once with $1 \mathrm{X}$ PBS before adding back $10 \mathrm{~mL}$ of fresh cDMEM. Spent media containing the packaged virus particles were harvested 48 and 72 hours later. The viral supernatant was filtered through a $0.45 \mu \mathrm{m}$

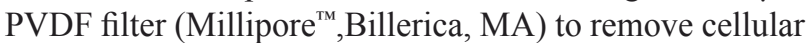
debris, aliquoted, and used fresh for subsequent retroviral transductions or stored frozen at $-80^{\circ} \mathrm{C}$ for later use. The viral supernatants were used to infected the various cell lines and stable transformed pools or either NGAL or pLXSN (empty vector control) were selected in media 
contain $2 \mathrm{mg} / \mathrm{ml} \mathrm{G} 418$ (Geneticin ${ }^{\circledR}$, Sigma-Aldrich) after 2-3 weeks of section. Medium was changed every 3 days with fresh medium containing $2 \mathrm{mg} / \mathrm{ml} \mathrm{G} 418$.

\section{Detection of Secreted NGAL}

Supernatant lysates used to determine the levels of NGAL protein in the supernatant were harvested and prepared as follows. All cell lines were plated in 6-well plates and cultured under normal culture conditions in cRPMI. Once the cells reached $80 \%$ confluency the media were removed, the cells were washed twice with $1 \mathrm{X}$ PBS, and $2 \mathrm{~mL}$ of fresh RPMI without FBS was added back. After 24 hours, the supernatants were harvested, cleared of cellular debris via centrifugation, and processed. Total protein from the collected supernatants was isolated by mixing $1 \mathrm{~mL}$ of the sample with $250 \mu \mathrm{L}$ of $100 \%(\mathrm{w} / \mathrm{v})$ trichloroacetic acid (TCA) (Sigma-Aldridge, Saint Louis, $\mathrm{MO}$ ) and incubating the mixture at $4^{\circ} \mathrm{C}$ for 15 minutes. The sample pellets were collected via centrifugation at 14000 RPM for 15 minutes. The pellets were washed twice with ice cold $100 \%$ acetone and allowed to air dry. The protein pellets were resuspended in $25 \mu \mathrm{L}$ of western sample buffer, boiled for 5 minutes, and examined by western blot analysis.

$20 \mu \mathrm{L}$ of the prepared supernatant samples was separated on $12 \%$ Tris-glycine poly-acrylamide gels and transferred to polyvinylidene fluoride (PVDF) membranes (Thermo Scientific, Rockford, IL). All membranes were blocked in 1X Tris-buffered saline + Tween-20 (TBST) (32 mM Tris, $125 \mathrm{mM} \mathrm{NaCl}, 0.5 \%$ Tween-20, $\mathrm{pH} 8$ ) containing $1 \%$ bovine serum albumin (BSA) (Fisher/ Thermo Scientific, Rockford, IL) overnight at $4^{\circ} \mathrm{C}$ with gently shaking. Blocked membranes were placed in appropriate dilutions of the NGAL antibody [50] in $1 \mathrm{x}$ TBST $+1 \%$ BSA overnight at $4{ }^{\circ} \mathrm{C}$ with gentle shaking. The next day, membranes were washed four times with $1 \mathrm{X}$ TBST before adding the appropriate secondary antibody made up in $1 \mathrm{X}$ TBST plus 5\% non-fat dry milk for one hour. After another round of four washes, the membranes were treated with horseradish peroxidase enhanced chemiluminescence (Pierce/Thermo Scientific, Rockford, IL) as per manufacturer's instructions and protein bands visualized via exposure to X-ray film (Research Products 42 International, Mount Prospect, IL). 0.1\% coomassie brilliant blue R250 (CBB) (Sigma-Aldrich) in a 50\% methanol $/ 7 \%$ acetic acid solution was used to stain total protein on the cellular supernatant immunoblots as a loading control.

\section{ACKOWLEDGEMENTS}

RA was supported in part by (PO1 CA49639). MC and GM were supported in part by grants from the Italian “'Ministero dell'Istruzione, dell'Università e della Ricerca
(Ministry forEducation, Universities and Research) MIUR” PRIN 2008 and FIRB-MERIT (RBNE08YYBM). $\mathrm{MC}$ was also supported in part by a grant to the CNR from the Italian Ministry of Economy and Finance for the Project FaReBio di Qualità. ML was supported in part by a grant from the Italian Ministry of Health, Ricerca Finalizzata Stemness 2008 entitled "Molecular Determinants of Stemness and Mesenchymal Phenotype in Breast Cancer". AMM was supported in part by grants from: Italian Ministry of Health Ricerca Finalizzata 2008 "Molecular therapy in pediatric sarcomas and leukemias against IGF-IR system: new drugs, best drug-drug interactions, mechanisms of resistance and indicators of efficacy", MIUR PRIN 2008 (2008THTNLC), and MIUR FIRB 2010 (RBAP10447J-003) and 2011 (RBAP11ZJFA_001). JP and RT were supported in part by a grant from Fondazione Umberto Veronesi entitled "Neutrophil gelatinase-associated lipocalin (NGAL) and matrix metalloproteinases (MMPS) as biomarkers of bladder cancer development and progression".

\section{REFERENCE}

1. Steelman LS, Chappell WH, Abrams SL, Kempf RC, Long J, Laidler P, Mijatovic S, Maksimovic-Ivanic D, Stivala F, Mazzarino MC, Donia M, Fagone P, Malaponte G, Nicoletti F, Libra M, Milella M, et al. Aging. 2011;3:192-222.

2. Chiavarina B. Whitaker-Menezes D. Migneco G. Martinez-Outschoorn UE. Pavlides S. Howell A. Tanowitz HB. Casimiro MC. Wang C. Pestell RG. Grieshaber P. Caro J. Sotgia F. Lisanti MP. HIF1-alpha functions as a tumor promoter in cancer associated fibroblasts, and as a tumor suppressor in breast cancer cells: Autophagy drives compartment-specific oncogenesis. Cell Cycle. 2011;9:3534-3551.

3. McCubrey JA, Steelman LS, Chappell WH, Abrams SL, Franklin RA, Montalto G, Cervello M, Nicoletti F, Fagone P, Malaponte G, Mazzarino MC, Candido S, Libra M, Bäsecke J, Milella M, Tafuri A et al. Mutations and deregulation of Ras/Raf/MEK/ERK and PI3K/PTEN/Akt/ mTOR cascades which alter therapy response. Oncotarget 2012;3:954-987.

4. Witkiewicz AK. Kline J. Queenan M. Brody JR. Tsirigos A. Bilal E. Pavlides S. Ertel A. Sotgia F. Lisanti MP. Molecular profiling of a lethal tumor microenvironment, as defined by stromal caveolin-1 status in breast cancers. Cell Cycle. 2011;10:1794-1809.

5. Godlewski J, Bronisz A, Nowicki MO, Chiocca EA, Lawler S. microRNA-451: A conditional switch controlling glioma cell proliferation and migration. Cell Cycle. 2010; 9: 27422748.

6. Oliveras-Ferraros C, Cufi S, Vazquez-Martin A, TorresGarcia VZ, Del Barco S, Martin-Castillo B, Menendez JA. Micro(mi)RNA expression profile of breast cancer epithelial cells treated with the anti-diabetic drug 
metformin: induction of the tumor suppressor miRNA let-7 $\mathrm{a}$ and suppression of the TGFbeta-induced oncomiR miRNA-181a. Cell Cycle. 2011;10:1144-1451.

7. Garcia JM, Silva J, Pena C, Garcia V, Rodríguez R, Cruz MA, Cantos B, Provencio M, España P, Bonilla F. Promoter methylation of the PTEN gene is a common molecular change in breast cancer. Genes Chromosomes Cancer. 2004; 41:117-124.

8. Wang L, Wang WL, Zhang Y, Guo SP, Zhang J, Li QL. Epigenetic and genetic alterations of PTEN in hepatocellular carcinoma. Hepatol Res. 2007;37:389-396.

9. Hochhaus A. La Rosee P. Muller MC. Ernst T. Cross NC. Impact of BCR-ABL mutations on patients with chronic myeloid leukemia.Cell Cycle. 2011;10:250-260.

10. Chomel JC. Turhan AG. Chronic myeloid leukemia stem cells in the era of targeted therapies: resistance, persistence and long-term dormancy. Oncotarget. 2011;2:713-727.

11. Martinez-Outschoorn UE. Trimmer C. Lin Z. WhitakerMenezes D. Chiavarina B. Zhou J. Wang C. Pavlides S. Martinez-Cantarin MP. Capozza F. Witkiewicz AK. Flomenberg N. Howell A. Pestell RG. Caro J. Lisanti MP. Sotgia F. Autophagy in cancer associated fibroblasts promotes tumor cell survival: Role of hypoxia, HIF1 induction and NFkappaB activation in the tumor stromal microenvironment. Cell Cycle. 2010;9:3515-3533.

12. Pavlides S. Tsirigos A. Vera I. Flomenberg N. Frank PG. Casimiro MC. Wang C. Pestell RG. Martinez-Outschoorn UE. Howell A. Sotgia F. Lisanti MP. Transcriptional evidence for the "Reverse Warburg Effect" in human breast cancer tumor stroma and metastasis: similarities with oxidative stress, inflammation, Alzheimer's disease, and "Neuron-Glia Metabolic Coupling". Aging. 2010;2:185199.

13. Martinez-Outschoorn UE. Prisco M. Ertel A. Tsirigos A. Lin Z. Pavlides S. Wang C. Flomenberg N. Knudsen ES. Howell A. Pestell RG. Sotgia F. Lisanti MP. Ketones and lactate increase cancer cell „stemness,“ driving recurrence, metastasis and poor clinical outcome in breast cancer: achieving personalized medicine via Metabolo-Genomics. Cell Cycle. 2011;10:1271-1286.

14. Yan L, Borregaard N, Kjeldsen L, Moses MA. The high molecular weight urinary matrix metalloproteinase (MMP) activity is a complex of gelatinase B/MMP-9 and neutrophil gelatinase B/MMP-9 and neutrophil gelatinase-associated lipocalin (NGAL). Modulation of MMP-9 activity by NGAL. J Biol Chem. 2001;276: 37258-37265.

15. Roy R, Lousi G, Loughlin KR, Wiederschain D, Kilroy SM, Lamb CC, Zurakowski D, Moses MD. Tumorspecific urinary matrix metalloproteinase fingerprinting: identification of high molecular weight urinary matrix metalloproteinase species. Clin Cancer Res. 2008;14:66106617.

16. Yang J, Bielenberg DR, Rodig SJ, Doiron R, Clifton MC, Kung AL, Strong RK, Zurakowski D, Moses MA. Lipocalin 2 promotes breast cancer progression. Proc Natl Acad Sci
USA. 2009; 106:3913-3918.

17. Yang J, Moses MA. Lipocalin 2: a multifaceted modulator of human cancer. Cell Cycle. 2009;8:2347-2352.

18. Bolignano D, Donato V, Lacquaniti A, Fazio MR, Bono C, Coppolino G, Buemi M. Neutrophi gelatinase-associated lipocalin (NGAL) in human neoplasias: a new protein enters the scene. Cancer Letters. 2010;288:10-16.

19. Leng X, Wu Y, Arlinghaus RB. Relationships of lipocalin 2 with breast tumorigenesis and metastasis. J Cell Physiol. 2011;226:309-314.

20. Shen F, Hu Zihua, Goswami J, Gaffen SL. Identification of common transcriptional regulatory elements in interleukin-17 target genes. J Biol Chem 2006;281:2413824148.

21. Matsuo S, Yamazaki S, Takeshige K, Muta T. Crucial roles of binding sites for NF- $\kappa \mathrm{B}$ and $\mathrm{C} / \mathrm{EBP}$ in I $\kappa \mathrm{B}$-zeta-mediated transcriptional activation. Biochem J. 2007;405:605-615.

22. Roukenar MH, Kuwahara Y, Baba T, Roushandeh AM, Ebishima S, Abe S, Ohkubo Y, Fukumoto M. Oxidative stress induced lipocalin 2 gene expression: addressing its experession under the harmful conditions. J Radiat Res. 2007;48:39-44.

23. Iannetti A, Pacifico F, Acquaviva R, Lavorgna A, Crescenzi E, Vascotto C, Tell G, Salzano AM, Scaloni A, Vuttariello E, Chiappetta G, Formisano S, Leonardi A. The neutrophils gelatinase-associated lipocalin (NGAL) a NF-kappaBregulated gene, is a survival factor for thyroid neoplastic cells. Proc Natl Acad Sci USA. 2008;105:14058-14063.

24. Bauer M, Eickhoff JC, Gould MN, Mundhenke C, Maass $\mathrm{N}$, Friendl A. Neutrophil gelatinase-associated lipocalin (NGAL) is a predictor of poor prognosis in human primary breast cancer. Breast Cancer Res Treat. 2008;108:389-397.

25. Steelman LS, Franklin RA, Abrams SL, Chappell W, Kempf CR, Bäsecke J, Stivala F, Donia M, Fagone P, Nicoletti F, Libra M, Ruvolo P, Ruvolo V, Evangelisti C, Martelli AM, McCubrey JA. Roles of the Ras/Raf/MEK/ ERK Pathway in Leukemia Therapy. Leukemia. 2011: 25:1080-94.

26. Barre B, Coqueret O, Perkins ND. Regulation of activity and function of the p52 NF-kappaB subunit following DNA damage. Cell Cycle. 2010;9:4795-4804.

27. Melvin A, Mudie S, Rocha S. Further insights into the mechanism of hypoxia-induced NFkappaB. Cell Cycle. 2011;10:879-882.

28. Bao G, Clifton M, Hoette TM, Mori K, Deng SX, Qiu A, Viltard M, Williams D, Paragas N, Leete T, Kulkarni R, Li X, Lee B, Kalandadze A, Ratner AJ, Pizarro JC et al. Iron traffics in circulation bound to a siderocalin (Ngal)-catechol complex. Nat Chem Biol. 2010;6:602-609.

29. Yu Y, Kovacevic Z, Richardson DR. Tuning cell cycle regulation with an iron key. Cell Cycle. 2007;6:1982-1994.

30. Le NT, Richardson DR. Iron chelators with high antiproliferative activity up-regulate the expression of a growth inhibitory and metastasis suppressor gene: a 
link between iron metabolism and proliferation. Blood. 2004; 104:2967-2975

31. Kovacevic Z, Richardson DR. The metastasis suppressor, Ndrg-1: a new ally in the fight against cancer. Carcinogenesis. 2006;27:2355-2366.

32. Kovacevic Z, Fu D, Richardson DR. The iron-regulated metastasis suppressor, Ndrg-1: identification of novel molecular targets. Biochim Biophys Acta. 2008;1783:19811992.

33. Assinder SJ, Dong Q, Kovacevic Z, Richardson DR. The TGF-beta, PI3K/Akt and PTEN pathways: established and proposed biochemical integration in prostate cancer. Biochem J. 2009;417:411-421.

34. Kovacevic Z, Chikhani S, Lui GY, Sivagurunathan S, Richardson DR. The Iron-Regulated Metastasis Suppressor NDRG1 Targets NEDD4L, PTEN, and SMAD4 and Inhibits the PI3K and Ras Signaling Pathways. Antioxid Redox Signal. 2012 In Press.

35. Yu Y, Gutierrez E, Kovacevic Z, Saletta F, Obeidy P, Suryo Rahmanto Y, Richardson DR. Iron chelators for the treatment of cancer. Curr Med Chem. 2012;19:2689-2702.

36. Buss JL, Greene BT, Turner J, Torti FM, Torti SV. Iron chelators in cancer chemotherapy. Curr Top Med Chem. 2004;4:1623-1635.

37. Harrison LB, Chadha M, Hill RJ, Hu K, Shasha D. Impact of tumor hypoxia and anemia on radiation therapy outcomes. Oncologist. 2002;7:492-508.

38. Sarafanov AG, Todorov TI, Centeno JA, Macias V, Gao W, Liang WM, Beam C, Gray MA, Kajdacsy-Balla AA. Prostate cancer outcome and tissue levels of metal ions. Prostate. 2011;71:1231-1238.

39. Guo W, Schlicht M, Kucynda T, Zhou P, Valyi-Nagy $\mathrm{K}$, Kajdacsy-Balla A. Iron increases the invasiveness of prostate cancer cells in vitro: Mechanisms and inhibition by the antioxidant ebselen. Cancer Research 2012;72: Supplement 1: doi:10.1158/1538-7445.AM2012-4322.

40. Pavlides S. Tsirigos A. Migneco G. Whitaker-Menezes D. Chiavarina B. Flomenberg N. Frank PG. Casimiro MC. Wang C. Pestell RG. Martinez-Outschoorn UE. Howell A. Sotgia F. Lisanti MP. The autophagic tumor stroma model of cancer: Role of oxidative stress and ketone production in fueling tumor cell metabolism. Cell Cycle. 2010;17:34853505, 2010.

41. Demaria M. Giorgi C. Lebiedzinska M. Esposito G. D’Angeli L. Bartoli A. Gough DJ. Turkson J. Levy DE. Watson CJ. Wieckowski MR. Provero P. Pinton P. Poli V. A STAT3-mediated metabolic switch is involved in tumour transformation and STAT3 addiction. Aging. 2010;2:823842 .

42. Brazzolotto X. Andriollo M. Guiraud P. Favier A. Moulis JM. Interactions between doxorubicin and the human iron regulatory system. Biochimica et Biophysica Acta. 2003; 1593:209-218.

43. Davies NP. Suryo Rahmanto Y. Chitambar CR. Richardson
DR. Resistance to the antineoplastic agent gallium nitrate results in marked alterations in intracellular iron and gallium trafficking: identification of novel intermediates. Journal of Pharmacology \& Experimental Therapeutics. 2006; 317:153-162.

44. Whitnall M. Howard J. Ponka P. Richardson DR. A class of iron chelators with a wide spectrum of potent antitumor activity that overcomes resistance to chemotherapeutics. Proc Nat Aca Sci USA. 2006;103:14901-14906.

45. Ganguly A. Chakraborty P. Banerjee K. Chatterjee S. Basu S. Sarkar A. Chatterjee M. Choudhuri SK. Iron N-(2hydroxy acetophenone) glycinate (FeNG), a non-toxic glutathione depletor circumvents doxorubicin resistance in Ehrlich ascites carcinoma cells in vivo. BioMetals. 2012;25:149-163.

46. Monier F, Mollier S, Guillot M, Rambeaud JJ, Morel F, Zaoui P. Urinary relase of 72 and $92 \mathrm{kDa}$ gelatinases, TIMP, N-GAL and conventional prognostic factors in urothelial carcinomas. Eur Urol. 2002;42:356-363.

47. Smith ER, Zurakowski D, Saad A, Scott RM, Moses MA. Urinary biomarkers predict brain tumor presence and response to therapy. Clin Cancer Res. 2008;14:2378-2386.

48. Roy R, Yang J, Moses MA. Matrix metalloproteinases as novel biomarkers and potential therapeutic targets in human cancer. J Clin Oncol. 2009;27:5287-5297

49. Schmidt C. Urine biomarkers may someday detect even distant tumors. JNCI. 2009;101:8-10.

50. Leng X, Ding T, Lin H, Wang Y, Hu L, Hu J, Feig B, Zhang W, Puszai L, Symmans WF, Wu Y, Arlinghaus RB. Inhibition of lipocalin 2 impairs breast tumorigensis and metastasis. Cancer Res. 2009;69:8579-8584.

51. Hu L, Hittelman W, Lu T, Ji P, Arlinghaus R, Shmulevich I, Hamilton SR, Zhang W. NGAL decreases E-cadherinmediated cell-cell adhesion and increases cell motility and invasion through Rac1 in colon carcinoma cells. Lab Invest. 2009;89:531-548.

52. Sun Y, Yokoi K, Li H, Gao J, Hu L, Liu B, Chen K, Hamilton SR, Fan D, Sun B, Zhang W. NGAL expression is elevated in both colorectal adenoma-carcinoma sequence and cancer progression and enhances tumorigenesis in xenograft mouse models. Clin Cancer Res. 2011;17:43314340).

53. Fernandez CA, Yan L, Louis G, Yang J, Kutok JL, Moses MA. The matrix metalloproteinase-9/neutrophil gelatinaseassociated lipocalin complex plays a role in breast tumor growth and is present in the urine of breast cancer patients Clin Cancer Res 2005;11:5390-5395.

54. Hu J, Van den Steen PE, Sang Q-X, Opdenakker G. Matrix metalloproteinase inhibitors as therapy for inflammatory and vascular diseases. Nat Rev Drug Dis. 2007;6:480-498.

55. Bourguignon LY, Gunja-Smith Z, Iida N, Zhu HB, Young LJ, Muller WJ, Cardiff RD. CD44v(3,8-10) is involved in cytoskeleton-mediated tumor cell migration and matrix metalloproteinase (MMP-9) association in metastatic breast 
cancer cells. J Cell Physiol. 1998; 176:206-215.

56. $\mathrm{Yu}$ Q, Stamenkovic I. Localization of matrix metalloproteinase 9 to the cell surface provides a mechanism for CD44-mediated tumor invasion. Genes Dev. 1999; 13:35-48.

57. Abecassis I, Olofsson B, Schmid M, Zaleman G, Kariguian A. RhoA induces MMP-9 expression at CD44 lamellipodial focal complexes and promotes HMEC-1 cell linvasion. Exp Cell Res. 2003; 291:363-376.

58. Egeblad M, Werb Z. New functions for the matrix metalloproteinases in cancer progression. Nat Rev Can. 2002;2:161-174.

59. Chappell WH, Abrams SL, Stadelman KM, LaHair MM, Franklin RA, Cocco L, Evangelisti C, Chiarini F, Martelli AM, Steelman LS, McCubrey JM. Increased NGAL (Lnc2) expression after chemotherapeutic drug treatment. Adv Bio Reg. 2012;53: In Press

60. Bauer M, Eickhoff JC, Gould MN, Mundhenke C, Maass N, Friendl A. Neutrophil gelatinase-associated lipocalin (NGAL) is a predictor of poor prognosis in human primary breast cancer. Breast Cancer Res Treat. 2008;108:389-397.

61. Provatopoulou X, Gounaris A, Kalogera E, Zagouri F, Flessas I, Goussetis E, Nonni A, Papassotiriou I, Zografos G. Circulating levels of matrix metalloproteinase-9 (MMP9), neutrophil gelatinase-associated lipocalin (NGAL) and their complex MMP-9/NGAL in breast cancer disease. BMC Cancer. 2009;9:390.

62. Steelman LS, Navolanic PN, Sokolosky M, Taylor JR, Lehmann BD, Chappell WH, Abrams SL, Wong EW, Stadelman K, Terrian DM, Leslie N, Martelli AM, Stivala F, Libra M, Franklin RA, McCubrey JA. Suppression of PTEN function increases breast cancer chemotherapeutic drug resistance while conferring sensitivity of mTOR inhibitors. Oncogene. 2008;27:4086-4095. 